\title{
Fenpyroximate for the control of Tetranychus ogmophallos and Mononychellus planki (Acari: Tetranychidae) in the peanut crop
}

\section{Fenpyroximate para o controle de Tetranychus ogmophallos e de Mononychellus planki (Acari: Tetranychidae) na cultura do amendoim}

\author{
Fabiano Aparecido dos SANTOS ${ }^{1}$; Cirano Cruz MELVILLE²; Daniel Junior de ANDRADE ${ }^{3}$
}

\begin{abstract}
${ }^{1}$ Autor para correspondência. Engenheiro Agrônomo. Programa de Pós-graduação em Agronomia (Entomologia Agrícola). Laboratório de Acarologia, Departamento de Fitossanidade, Faculdade de Ciências Agrárias e Veterinárias, Universidade Estadual de São Paulo - UNESP, Via de Acesso Prof. Paulo Donato Castellane, s/n, CEP 14884-900, Jaboticabal, SP, Brasil. Email.: fabiano.unesp_@hotmail.com

${ }^{2}$ Mestre em Agronomia (Entomologia Agrícola). Laboratório de Acarologia, Departamento de Fitossanidade, Faculdade de Ciências Agrárias e Veterinárias, Universidade Estadual de São Paulo - UNESP, Via de Acesso Prof. Paulo Donato Castellane, s/n, CEP 14884-900, Jaboticabal, SP, Brasil. Email.: ciranomelville@outlook.com

${ }^{3}$ Professor Doutor. Laboratório de Acarologia, Departamento de Fitossanidade, Faculdade de Ciências Agrárias e Veterinárias, Universidade Estadual de São Paulo - UNESP, Via de Acesso Prof. Paulo Donato Castellane, s/n, CEP 14884900, Jaboticabal, SP, Brasil. Email.: daniel.andrade@fcav.unesp.br
\end{abstract}

Recebido em: 10-11-2016; Aceito em: 25-07-2017

\begin{abstract}
The mites Tetranychus ogmophallos and Mononychellus planki are emerging pests in the peanut crop and have been causing great economic damage. The objective of this work was to evaluate the acaricide fenpyroximate in the control of T. ogmophallos and M. planki mites in the peanut crop. The experiments were carried out under laboratory and field conditions. In the laboratory, experiments were performed using peanut leaf discs placed on Petri dishes containing $2 \%$ agar-water. Adult $T$. ogmophallos or $M$. planki mites were transferred to each experimental unit and exposed to different concentrations of fenpyroximate using a Potter tower. After defining the most efficient concentrations, a field experiment was carried out in a peanut cultivation area. In this area, infestation with $T$. ogmophallos mites was carried out at 30 days after emergence of the peanut plants, while $M$. planki occurred naturally in the area. Then, fenpyroximate applications were performed with a pressurized costal sprayer. In the laboratory, fenpyroximate was efficient in controlling T. ogmophallos and M. planki at concentrations above $2.5 \mathrm{~g}$ a.i. $100 \mathrm{~L}^{-1}$. Under field conditions, fenpyroximate was effective against these mites at all concentrations evaluated $\left(10,15,20\right.$ and $30 \mathrm{~g}$ a.i. $\left.100 \mathrm{~L}^{-1}\right)$.
\end{abstract}

Additional keywords: abamectin; Arachis hypogaea; emerging pest; peanut red mite; soybean green mite.

\section{Resumo}

Os ácaros Tetranychus ogmophallos e Mononychellus planki são pragas emergentes na cultura do amendoim e vêm causando grandes prejuízos econômicos. O objetivo do trabalho foi avaliar o acaricida fenpyroximate no controle dos ácaros $T$. ogmophallos e M. planki na cultura do amendoim. Os experimentos foram realizados em laboratório e campo. Em laboratório, foram realizados experimentos utilizando-se discos de folhas de amendoim colocados sobre placas de Petri contendo ágar-água a $2 \%$. Ácaros adultos de T. ogmophallos ou M. planki foram transferidos para cada unidade experimental e expostos a diferentes concentrações de fenpyroximate utilizando torre de Potter. Após a definição das concentrações mais eficientes, foi realizado um experimento a campo em área de cultivo de amendoim. Nesta área, efetuou-se uma infestação com ácaros $T$. ogmophallos em 30 dias após a emergência das plantas de amendoim, enquanto que $M$. planki ocorreu naturalmente na área. Em seguida, realizaram-se as aplicações de fenpyroximate com pulverizador costal pressurizado. No laboratório, fenpyroximate foi eficiente no controle de $T$. ogmophallos e $M$. planki nas concentrações acima de $2,5 \mathrm{~g}$ i.a. $100 \mathrm{~L}^{-1}$. Em condições de campo, fenpyroximate foi eficiente contra estes ácaros em todas as concentrações avaliadas $\left(10,15,20\right.$ e 30 g i.a. $\left.100 \mathrm{~L}^{-1}\right)$.

Palavras-chave adicionais: abamectina; ácaro-verde-da-soja; ácaro-vermelho-do-amendoim; Arachis hypogaea; praga emergente.

\section{Introduction}

Peanut (Arachis hypogaea L.) is an oilseed of great economic importance, with a worldwide production of more than 40 million tons of grains to meet both the food and the oleochemical market (Graciano et al., 2011). In the world ranking, Brazil is the 11th largest producer and the 2nd largest exporter of peanuts (USDA, 2016).

If the phytosanitary control is not carried out 
properly, several pests can reduce peanut yield (Lourenção et al., 2007). In recent years, peanut yield reductions caused by the mites Tetranychus ogmophallos Ferreira \& Flechtmann (Acari: Tetranychidae) and Mononychellus planki (McGregor) (Acari: Tetranychidae) have been causing concern to producers. These mites are considered as emerging pests and can cause irreversible damage to peanuts, leading to the death of plants (Ferreira \& Flechtmann, 1997; Lourenção et al., 2001).

Some hypotheses are suggested to explain the outbreaks of these mites occurring in recent years. These include the planting of new varieties that may favor mites, changes in planting systems and prolonged droughts during the summer ("Indian Summers").

The feeding of the mite T. ogmophallos results in a widespread silvering of leaves, followed by necrosis and fall (Lourenção et al., 2001). Peanut plants infested with $T$. ogmophallos in the early stages of development may die. If infestation occurs at 90 days after emergence, the yield reduction may reach up to 85\% (Melville, 2015). On the other hand, the feeding of M. planki results in whitish spots on the leaves and loss of brightness, popularly known as "mottling". According to Moraes \& Flechtmann (2008), M. planki has a high potential to cause damage to peanut.

Because they are emerging pests, the management of $T$. ogmophallos and $M$. planki is quite limited and there is little knowledge about these species in the peanut crop (Andrade et al., 2016). Fenpyroximate may be an alternative for the control of these mites, since it is an acaricide that acts to inhibit the NADH-ubiquinone reductase (complex I) of the respiratory chain (Ay \& Kara, 2011). This acaricide is interesting for the management of pest mites, as studies demonstrate its efficiency in the control of Tetranychus kanzawai Kishida (Acari: Tetranychidae) (Kim \& Paik, 1996) and Tetranychus urticae Koch (Acari: Tetranychidae) (Veronez et al. 2012). In addition to its efficiency in controlling some insect pests, fenpyroximate is selective to the mite Neoseiulus womersleyi (Schicha) (Acari: Phytoseiidae), the main predator of T. kanzawai (Kim \& Paik, 1996).

In Brazil, fenpyroximate is recorded to control mites in crops of coffee, citrus, coconut, apple, papaya, strawberry, rose and tomato (Agrofit, 2016), and may become an alternative for the control of $T$. ogmophallos and $M$. planki in the peanut crop. Thus, the present study was carried out to evaluate the effect of fenpyroximate on T. ogmophallos and M. planki in the peanut crop.

\section{Material and methods}

\section{Study site}

The experiments were carried out in the Laboratory of Acarology and in an experimental area of the Department of Plant Health of the Paulista State University/Faculty of Agrarian and Veterinary Sciences
(FCAV/UNESP), Jaboticabal-SP Campus. The experiments were conducted under the authorization of the Ministry of Agriculture, Livestock and Supply (MAPA), through the Temporary Special Registry of Agrochemicals and Allied Products (RET).

\section{Breeding of mites}

The breedings were established with T. ogmophallos and M. planki mites collected in plants of the peanut cv. Granoleico in the experimental area of FCAV/UNESP.

T. ogmophallos mites were breeded in a greenhouse on plants of the peanut cv. Granoleico planted in ten-liter pots. The plants used in the breeding were replaced weekly by healthy plants, to which the mites could migrate easily by just approximating them.

The breeding of M. planki was established on leaflets of plants of the peanut cv. Granoleico. The leaflets were placed in 14-cm-diameter Petri dishes containing a $1-\mathrm{cm}$ foam layer, and wrapped with a hydrophilic cotton layer to maintain turgescence and to prevent mite escape. Periodically, the leaflets were replaced to ensure the food of the mites. The breeding was maintained in an air-conditioned room with a temperature of $25 \pm 1 \stackrel{\circ}{ } \mathrm{C}$, relative humidity of $60 \pm 5 \%$ and photoperiod of 12 hours.

\section{Laboratory experiments}

The laboratory experiments were started in August 2013. For the experiments, 2.5-cm-diameter leaf discs were sectioned from leaflets of plants of the peanut cv. Granoleico with the aid of metal spouts. Then, the discs were surrounded with entomological glue barrier for containing the mites and placed in 14-cm-diameter Petri dishes containing $2 \%$ agar-water. Two similar experiments were performed to evaluate the action of the acaricide fenpyroximate on T. ogmophallos and M. planki. Each experiment was composed of seven treatments with eight replicates. The treatments were fenpyroximate (Ortus $50 \mathrm{SC}^{\circledR}$ ) at the concentrations of 1.0, 2.5, 5.0, 7.5 and $10.0 \mathrm{~g}$ a.i. $100 \mathrm{~L}^{-1}$, abamectin (Kraft $36 \mathrm{EC}^{\circledR}$ ) at $0.54 \mathrm{~g}$ a.i. $100 \mathrm{~L}^{-1}$ and a control with deionized water. The abamectin concentration used in these experiments was based on studies carried out by Vásquez \& Ceballos (2009). Each experimental unit consisted of a leaf disc. Ten adult females of $T$. ogmophallos or $M$. planki with approximately 15 days of age were transferred, with the aid of a single-hair brush, to each experimental unit.

The applications of the acaricides were carried out under a Potter tower at $27.58 \mathrm{kPa}\left(4 \mathrm{lb} \mathrm{pol}^{-2}\right)$. Two militers of syrup were inserted into the Potter tower with a deposition of $1.56 \mathrm{mg} \mathrm{cm}^{-2}$. After the applications, the leaf discs were taken to a climatized chamber with a temperature of $25 \pm 1 \stackrel{\circ}{ } \mathrm{C}$, relative humidity of $60 \pm 5 \%$ and photoperiod of 12 hours. The evaluations for quantification of dead mites, live mites 
and mites retained in the glue barrier were performed at 1,3 and 5 days after application (DAA). The mites that did not move after the touch of the single-hair brush were considered dead.

\section{Field Experiment}

For the installation of the field experiment, an area cultivated with the peanut cv. Granoleico, located at FCAV/UNESP (coordinates: 48 $17^{\prime} 11.65^{\prime \prime} \mathrm{W}$ latitude, $21^{\circ} 14^{\prime 22.20 "} S$ longitude and altitude of 589 meters), was selected. 30 days prior to planting, in the soil preparation stage, correction fertilization was performed with $50 \mathrm{~kg} \mathrm{ha}^{-1} \mathrm{P}_{2} \mathrm{O}_{5}, 50 \mathrm{~kg}^{-1} \mathrm{~K}_{2} \mathrm{O}$ and $10 \mathrm{~kg} \mathrm{ha}^{-1} \mathrm{~N}$ in the formula $4-20-20$ (N-P-K). The spatial arrangement of sowing was $90 \mathrm{~cm}$ between rows and density of 15 seeds per meter. In this area, peanut sowing was performed on November 19, 2013. Twenty-four experimental plots were demarcated, each plot being 6 meters long by 4 meters wide.

The artificial infestation of the area with T. ogmophallos mites was performed thirty days after the germination of the plants, and leaves of peanut plants collected in the breeding area containing large numbers of mites were distributed. $M$. planki mite infestation occurred naturally in the area. A preliminary evaluation was performed three days before the application of the acaricides. After estimating the initial population density of mites, the plots were distributed among the treatments to maintain their uniformity.

The experiment was carried out in a randomized complete block design with 6 treatments and 4 replicates. Four treatments contained different concentrations of fenpyroximate (Ortus $\left.50 \mathrm{SC}^{\circledR}\right)(10,15$, 20 and $30 \mathrm{~g}$ a.i. $100 \mathrm{~L}^{-1}$ ), in addition to a treatment with abamectin (Kraft $\left.36 \mathrm{EC}^{\circledR}\right)\left(4.32 \mathrm{~g}\right.$ a.i. $\left.100 \mathrm{~L}^{-1}\right)$ and a control without application. The acaricide concentrations used in the experiments were based on recommendations of the commercial products available for other crops. The concentrations of fenpyroximate and abamectin were based on the concentrations used for the control of the two-spotted spider mite in rose and cotton, respectively (Agrofit, 2013).

The applications of the acaricides were carried out on March 1, 2014. A CO 2 costal sprayer was used, equipped with a bar with 6 spray tips (type XR11002) spaced $50 \mathrm{~cm}$ apart and under a pressure of $241.32 \mathrm{kPa} \quad\left(35 \mathrm{lb} \mathrm{pol}^{-2}\right)$. The volume of syrup applied in the treatments was equivalent to $250 \mathrm{~L} \mathrm{ha}^{-1}$. Evaluations of tetranychid mite populations were performed at 7, 14 and 21 DAA. Two samples of 10 leaves (40 leaflets) were collected per plot, one sample being collected in the basal region and the other in the apical region of the plants.

Throughout the development of the crop, treatments with the fungicides epoxiconazole (Opera $50 \mathrm{SE}^{\circledR}$ ) and chlorothalonil (Bravonil $500 \mathrm{SC}^{\circledR}$ ) were carried out at $35,45,60$ and 90 days after sowing. The fungicide concentrations used were 0.6 L. c.p. ha ${ }^{-1}$ epoxiconazole and 2.5 L c.p. ha ${ }^{-1}$ chlorothalonil. Except for fungicides and acaricides (treatments), no other pesticides were applied during the development of the crop.

\section{Data Analysis}

Mortality percentages in the laboratory experiments were calculated by the Abbott formula (1925) and transformed into Arc sine (Root $(x / 100))$ to be submitted to analysis of variance (ANOVA), with means compared by Tukey test $(P<0.05)$.

Mortality percentages in the field experiment were calculated by the Henderson \& Tilton formula (1955). Subsequently, these percentages were transformed into Arc sine (Root $(x / 100))$ to be submitted to analysis of variance (ANOVA), with means compared by Tukey test $(\mathrm{P}<0.05)$.

\section{Results and discussion}

\section{Laboratory experiments}

In these experiments, the acaricidal action of fenpyroximate on $T$. ogmophallos and $M$. planki was confirmed. In general, after the third day of application, there was a high mortality of $T$. ogmophallos and M. planki mites in all treatments (Table 1). Fenpyroximate at $1.0 \mathrm{~g}$ a.i. $100 \mathrm{~L}^{-1}$ at $1 \mathrm{DAA}$ was the only treatment that did not reach mortality values above $50 \%$ on both mites (Table 1). In addition, fenpyroximate concentrations of 1.0 and $2.5 \mathrm{~g}$ a.i. $100 \mathrm{~L}^{-1}$ on the green mite M. planki showed lower values than the other treatments in the first two evaluations. Notwithstanding, the concentration of 1.0 $g$ a.i. $100 \mathrm{~L}^{-1}$ was the only one that did not result in $100 \%$ mortality at 5 DAA on the green mite (Table 1).

Fenpyroximate concentrations above $5.0 \mathrm{~g}$ a.i.

$100 \mathrm{~L}^{-1}$ and treatment with abamectin caused $100 \%$ mortality on T. ogmophallos at 1 DAA (Table 1). Also on T. ogmophallos, the concentration of $2.5 \mathrm{~g}$ a.i. 100 $\mathrm{L}^{-1}$ fenpyroximate caused $100 \%$ mortality at 3 DAA. On the other hand, treatment with $1.0 \mathrm{~g}$ a.i. $100 \mathrm{~L}^{-1}$ resulted in $89.3 \%$ mortality only at 5 DAA (Table 1). Similar results were verified by Ghaderi et al. (2012) and by Veronez et al. (2012). Ghaderi et al. (2012) studied the effect of fenpyroximate at the concentration of $1.9 \mathrm{~g}$ a.i. $100 \mathrm{~L}^{-1}$ on the two-spotted spider mite $T$. urticae under laboratory conditions. These authors also verified a high mortality of $T$. urticae with the mentioned concentration of the product. Likewise, Veronez et al. (2012) obtained mortality values superior to $83 \%$ with fenpyroximate at the concentration of $5 \mathrm{~g}$ a.i. $100 \mathrm{~L}^{-1}$ for $T$. urticae kept on common bean.

\section{Field experiment}

The preliminary evaluation performed 3 days prior to the applications showed no significant difference between the treatments in the initial number of mites, indicating uniformity in the experimental area in the T. ogmophallos $\left(F_{5,18}=0.43 ; P=0.82\right)$ and M. planki $\left(\mathrm{F}_{5,18}=0.53 ; \mathrm{P}=0.75\right)$ infestations. The mean number of mites per leaflet recorded in the preliminary evaluation was $3.05 \pm 1.06$ for $T$. ogmophallos and $3.1 \pm 0.59$ for M. planki. 
Immediately after application of the products, T. ogmophallos and M. planki mite populations were reduced in all treatments, with the population level of both species remaining low until the end of the experiment (Table 2). All treatments with fenpyroximate showed similar control to the treatment with abamectin, except for M. planki. In this experiment, the mortality results obtained for abamectin in the control of the green mite were inferior to the other treatments in the first two evaluations (Table 2).

Table 1 - Percentage of mortality (mean \pm SEM) of Tetranychus ogmophallos and Mononychellus planki at 1, 3 and 5 days after application (DAA) of fenpyroximate and abamectin under Potter spray tower.

\begin{tabular}{|c|c|c|c|c|}
\hline \multicolumn{5}{|c|}{ Tetranychus ogmophallos } \\
\hline Treatments & $\begin{array}{l}\text { Concentration } \\
\left(\mathrm{g} \text { a.i. } 100 \mathrm{~L}^{-1}\right)\end{array}$ & $1 \mathrm{DAA}$ & $3 \mathrm{DAA}$ & $5 \mathrm{DAA}$ \\
\hline Fenpyroximate & 1.00 & $44.2 \pm 7.79 \mathrm{~b}$ & $72.7 \pm 7.66 b$ & $89.3 \pm 6.04 b$ \\
\hline Fenpyroximate & 2.50 & $91.5 \pm 4.68 \mathrm{a}$ & $100.0 \pm 0.00 \mathrm{a}$ & $100.0 \pm 0.00 \mathrm{a}$ \\
\hline Fenpyroximate & 5.00 & $100.0 \pm 0.00 \mathrm{a}$ & $100.0 \pm 0.00 \mathrm{a}$ & $100.0 \pm 0.00 \mathrm{a}$ \\
\hline Fenpyroximate & 7.50 & $100.0 \pm 0.00 a$ & $100.0 \pm 0.00 a$ & $100.0 \pm 0.00 \mathrm{a}$ \\
\hline Fenpyroximate & 10.0 & $100.0 \pm 0.00 \mathrm{a}$ & $100.0 \pm 0.00 \mathrm{a}$ & $100.0 \pm 0.00 \mathrm{a}$ \\
\hline Abamectina & 0.54 & $100.0 \pm 0.00 \mathrm{a}$ & $100.0 \pm 0.00 \mathrm{a}$ & $100.0 \pm 0.00 \mathrm{a}$ \\
\hline $\mathrm{F}$ test & & $29.5^{\star \star}$ & $11.4^{\star *}$ & $3.9^{\star *}$ \\
\hline C.V. (\%) & & 13.2 & 10.3 & 7.9 \\
\hline \multicolumn{5}{|c|}{ Mononychellus planki } \\
\hline Treatments & $\begin{array}{l}\text { Concentration } \\
\left(\mathrm{g} \text { a.i. } 100 \mathrm{~L}^{-1}\right)\end{array}$ & $1 \mathrm{DAA}$ & $3 \mathrm{DAA}$ & $5 \mathrm{DAA}$ \\
\hline Fenpyroximate & 1.00 & $33.2 \pm 2.3 c$ & $53.8 \pm 1.6 \mathrm{c}$ & $65.3 \pm 7.3 b$ \\
\hline Fenpyroximate & 2.50 & $54.5 \pm 4.9 c$ & $91.8 \pm 5.5 b$ & $100.0 \pm 0.0 \mathrm{a}$ \\
\hline Fenpyroximate & 5.00 & $78.6 \pm 7.1 b$ & $100.0 \pm 0.0 \mathrm{a}$ & $100.0 \pm 0.0 \mathrm{a}$ \\
\hline Fenpyroximate & 7.50 & $93.5 \pm 4.0 \mathrm{ab}$ & $100.0 \pm 0.0 \mathrm{a}$ & $100.0 \pm 0.0 \mathrm{a}$ \\
\hline Fenpyroximate & 10.0 & $94.8 \pm 4.1 \mathrm{ab}$ & $100.0 \pm 0.0 \mathrm{a}$ & $100.0 \pm 0.0 \mathrm{a}$ \\
\hline Abamectina & 0.54 & $98.7 \pm 2.4 \mathrm{a}$ & $100.0 \pm 0.0 \mathrm{a}$ & $100.0 \pm 0.0 \mathrm{a}$ \\
\hline $\mathrm{F}$ test & & $22.5^{\star *}$ & $54.5^{\star *}$ & $19.3^{* *}$ \\
\hline C.V. (\%) & & 18.8 & 8.1 & 9.9 \\
\hline
\end{tabular}

The average mortalities obtained by the formula of Abbott (1925) presented are the original ones. Means followed by the same letter in the column do not differ according to Tukey test $(P \geq 0.05)$. $\left(^{* *}\right)$ significant at $1 \%$ probability. Original data transformed into Arc sine (Root (x/ 100)). C.V.- Coefficient of Variation.

Table 2 - Percentage of mortality (mean \pm SEM) of Tetranychus ogmophallos and Mononychellus planki at 7 , 14 and 21 days after application (DAA) in field using a hand operated knapsack sprayer.

\begin{tabular}{|c|c|c|c|c|}
\hline \multicolumn{5}{|c|}{ Tetranychus ogmophallos } \\
\hline \multirow{2}{*}{ Treatments } & \multirow{2}{*}{$\begin{array}{l}\text { Concentration } \\
\left(\mathrm{g} \text { a.i. } 100 \mathrm{~L}^{-1}\right)\end{array}$} & $7 \mathrm{DAA}$ & 14 DAA & $21 \mathrm{DAA}$ \\
\hline & & Efic. (\%) & Efic. (\%) & Efic. (\%) \\
\hline Fenpyroximate & 10 & $99.5 \pm 1.7 \mathrm{a}$ & $100.0 \pm 0.0 \mathrm{a}$ & $99.3 \pm 2.3 \mathrm{a}$ \\
\hline Fenpyroximate & 15 & $99.3 \pm 2.4 \mathrm{a}$ & $100.0 \pm 0.0 \mathrm{a}$ & $98.1 \pm 4.1 \mathrm{a}$ \\
\hline Fenpyroximate & 20 & $99.6 \pm 1.8 \mathrm{a}$ & $69.0 \pm 21.2 \mathrm{a}$ & $100.0 \pm 0.0 \mathrm{a}$ \\
\hline Fenpyroximate & 30 & $100.0 \pm 0.0 \mathrm{a}$ & $75.0 \pm 22.5 a$ & $92.8 \pm 8.1 \mathrm{a}$ \\
\hline Abamectina & 4.32 & $100.0 \pm 0.0 \mathrm{a}$ & $96.2 \pm 5.7 \mathrm{a}$ & $100.0 \pm 0.0 \mathrm{a}$ \\
\hline $\mathrm{F}$ test & - & $0.7^{\mathrm{NS}}$ & $0.9^{N S}$ & $0.6^{\mathrm{NS}}$ \\
\hline C.V. (\%) & - & 3.4 & 35.9 & 9.6 \\
\hline \multicolumn{5}{|c|}{ Mononychellus planki } \\
\hline \multirow{2}{*}{ Treatments } & \multirow{2}{*}{$\begin{array}{l}\text { Concentration } \\
\left(\mathrm{g} \text { a.i. } 100 \mathrm{~L}^{-1}\right)\end{array}$} & 7 DAA & $14 \mathrm{DAA}$ & $21 \mathrm{DAA}$ \\
\hline & & Efic. (\%) & Efic. (\%) & Efic. (\%) \\
\hline Fenpyroximate & 10 & $99.7 \pm 1.6 \mathrm{a}$ & $98.7 \pm 3.4 \mathrm{a}$ & $88.6 \pm 10.6 a$ \\
\hline Fenpyroximate & 15 & $100.0 \pm 0.0 \mathrm{a}$ & $100.0 \pm 0.0 \mathrm{a}$ & $93.7 \pm 7.5 \mathrm{a}$ \\
\hline Fenpyroximate & 20 & $100.0 \pm 0.0 \mathrm{a}$ & $95.0 \pm 5.5 \mathrm{a}$ & $100.0 \pm 0.0 \mathrm{a}$ \\
\hline Fenpyroximate & 30 & $96.7 \pm 5.3 \mathrm{a}$ & $100.0 \pm 0.0 \mathrm{a}$ & $97.1 \pm 5.0 \mathrm{a}$ \\
\hline Abamectina & 4.32 & $72.0 \pm 7.2 \mathrm{~b}$ & $48.5 \pm 7.8 b$ & $90.5 \pm 9.5 \mathrm{a}$ \\
\hline $\mathrm{F}$ test & - & $9.9^{* *}$ & $18.6^{\star *}$ & $0.31^{\mathrm{NS}}$ \\
\hline C.V. (\%) & - & 9.8 & 11.6 & 18.0 \\
\hline
\end{tabular}

The average mortalities obtained by the Henderson \& Tilton formula (1955) presented are the original ones. Means followed by the same letter in the column do not differ according to the Tukey test $(\mathrm{p} \geq 0.05)$; NS - not significant; $\left({ }^{* *}\right)$ significant at $1 \%$ probability; Original data transformed into Arc sine (Root (x/ 100)). C.V.- Coefficient of Variation. 
The treatments with fenpyroximate did not differ significantly in relation to the number of mites for both species (Table 2). The control percentages of fenpyroximate for $T$. ogmophallos varied from 69.0 to $100.0 \%$, while for $M$. planki the percentages ranged from 88.6 to $100 \%$ (Table 2). Similar results were found by Lima et al. (2013), who evaluated the effect of fenpyroximate on the coconut eriophyid mite Aceria guerreronis Keifer (Acari: Eriophyidae) and found that the $90 \%$ lethal concentration (90LC) of this product was $1.0138 \mathrm{~g}$ a.i. $100 \mathrm{~L}^{-1}$. Another study, developed Kim et al. (2006), evaluated the residual and sublethal effect of fenpyroximate on the instantaneous growth rate of $T$. urticae under laboratory conditions, being noted that concentrations above $0.62 \mathrm{~g}$ a.i. $100 \mathrm{~L}^{-1}$ caused a high mortality of $T$. urticae.

The lowest concentration of fenpyroximate evaluated in the present study was sufficient to substantially reduce the mite populations. In general, one should choose the lowest possible concentration that is efficient over the target for the recommendation of field pesticides, since the negative impact on the environment and man will probably be lower (Américo et al., 2015). Moreover, the cost of the application also tends to decrease with the reduction in concentration. Frequently, the pesticide concentrations used in the field are much higher than the doses evaluated in the laboratory. This fact can be explained by the abiotic factors that may affect the efficiency of the product, such as rain, temperature, wind, among others (Guedes et al., 2015). Factors related to the application technology and the technical capacity of the professional responsible for the application can also considerably affect the efficiency of a pesticide under field conditions (Baesso et al., 2014).

The efficiency of fenpyroximate for the control of $T$. ogmophallus and M. planki mites was observed in the present study and the recognition of the potential use of a phytosanitary product for the control of pest mites is of great importance for the management thereof. As abamectin is a commonly used product for the control of pest mites, knowledge of the potential use of fenpyroximate is an advantage for the management of mites in the peanut crop, since the availability of different products with different modes of action is desirable for the management of the resistance evolution of pest mites (Franco et al., 2007).

Fenpyroximate is a molecule with toxicity to other phytophagous tetranychids and selective for certain predatory mites (Motoba et al., 2000; Desai et al., 2014). However, probably due to the diversity of predatory mites, the use of fenpyroximate is not always safe for this group of beneficial organisms such as Phytoseiulus macropilis (Banks) (Acari: Phytoseiidae) (Veronez et al., 2012), Phytoseius plumifer (Canestrini \& Fanzago) (Acari: Phytoseiidae) (Hamedi et al., 2010) and Phytoseiulus persimilis Athias-Henriot (Acari: Phytoseiidae) (Nadimi et al., 2008).

Despite the potential of the acaricide fenpyroximate for the control of $T$. ogmophallos and M. planki mites in the peanut crop, a more detailed understanding on the toxicity of fenpyroximate to nontarget organisms and the evaluation of productresistance for pests present in this crop are critical before the recommendation and inclusion of fenpyroximate in IPM programs in the peanut crop.

\section{Conclusions}

Fenpyroximate is efficient in controlling the emerging pest mites T. ogmophallos and M. planki and may be a future option for the management of these arthropods in the peanut crop.

\section{References}

Abbott WSA (1925) method of computing the effectiveness of an insecticide. Journal of Economic Entomology 18(s.n): 265-267.

Agrofit - Sistema de agrotóxicos fitossanitários do Ministério da Agricultura, Pecuária e Abastecimento. Disponível em: $<$ http://extranet.agricultura.gov.br/agrofit_ cons/principal_agrofit_cons>. Acesso em: 01 set. 2016.

Agrofit - Sistema de agrotóxicos fitossanitários do Ministério da Agricultura, Pecuária e Abastecimento. Disponível em: $<$ http://extranet.agricultura.gov.br/agrofit_ cons/principal_agrofit_cons>. Acesso em: 01 ago. 2013.

Américo JHP, Manoel LO, Torres NH, Ferreira LFR (2015) O uso de agrotóxicos e os impactos nos ecossistemas aquáticos. Revista Científica ANAP Brasil 8(13):101-115.

Andrade DJ, Melville CC, Michelotto MD (2016) manual prático sobre ácaros do amendoim no Brasil. Funep. 22p.

Ay R, Kara FE (2011) Toxicity, inheritance of fenpyroximate resistance, and detoxification-enzyme levels in a laboratory-selected fenpyroximate resistant strain of Tetranychus urticae Koch (Acari: Tetranychidae). Crop Protection 30(6):605-610.

Baesso MM, Teixeira MM, Ruas RAA, Baesso RCE (2014) Tecnologias de aplicação de agrotóxicos. Revista Ceres 61(Suppl.)780-785.

Desai HR, Sojitra RS, Patel CJ, Maisuria IM, Kumar V (2014) Field evaluation for bio-efficacy of fenpyroximate 5 EC against leaf hopper and spider mite infesting cotton and their safety to natural enemies. Advance Research Journal of Crop Improvement 5(2):172-175. 
Ferreira DNM, Flechtmann CHW (1997) Two new phytophagous mites (Acari: Tetranychidae, Eriophyidae) from Arachis pintoi from Brazil. Systematic \& Applied Acarology 2(s.n):181-188.

Franco CR, Casarin NFB, Domingues FA, Omoto C (2007) Resistência de Brevipalpus phoenicis (Geijskes) (Acari: Tenuipalpidae) a acaricidas inibidores da respiração celular em citros: Resistência cruzada e custo adaptativo. Neotropical Entomology 36(4):565-576.

Ghaderi S, Minaee K, Akrami M, Aleosfour M (2012) The effect of fenpyroximate on life table parameters of Tetranychus urticae under laboratory conditions. Iranian Journal of Plant Protection Science 43(2):251-260 .

Graciano ESA, Nogueira RJMC, Lima DRM, Pacheco CM, Santos RC (2011) Crescimento e capacidade fotossintética da cultivar de amendoim BR 1 sob condições de salinidade. Revista Brasileira de Engenharia Agrícola e Ambiental 15(8):794-800.

Guedes RNC, Smagghe G, Stark JD, Desneux N (2015) Pesticide-Induced stress in arthropod pests for optimized integrated pest management programs. Annual Review of Entomology 61(1):43-62.

Hamedi N, Fathipour Y, Saber M (2010) Sublethal effects of abamectin on the biological performance of the predatory mite, Phytoseius plumifer (Acari: Phytoseiidae). Experimental and Applied Acarology 53(1):29-40.

Henderson CF, Tilton EW, (1955) Tests with Acaricides against the brown wheat mite. Journal of Economic Entomology 48(2):157-161.

Kim M, Sim C, Shin D, Suh E, Cho K (2006) Residual and sublethal effects of fenpyroximate and pyridaben on the instantaneous rate of increase of Tetranychus urticae. Crop Protection 25(6):542-548.

Kim SS, Paik HC (1996) Comparative toxicity of fenpyroximate to the predatory mite, Amblyseius womersleyi Schicha and the kanzawa spider mite, Tetranychus kanzawai Kishida (Acarina: Phytoseiidae, Tetranychidae). Applied Entomology and Zoology 31(3):369-377.

Lima DB, Monteiro VB, Guedes RNC, Siqueira HAA, Pallini A, Gondim Jr. MGC (2013) Acaricide toxicity and synergism of fenpyroximate to the coconut mite predator Neoseiulus baraki. BioControl 58(5):595-605.
Lourenção AL, Kasai FS, Návia D, Godoy IJ, Flechtmann CHW (2001) Ocorrência de Tetranychus ogmophallos Ferreira \& Flechtmann (Acari: Tetranychidae) em amendoim no Estado de São Paulo. Neotropical Entomology 30(3):495-496.

Lourenção AL, Moraes ARA, Godoy IJ, Ambrosano GMB (2007) Efeito da infestação de Enneothrips flavens Moulton sobre o desenvolvimento de cultivares de amendoim. Bragantia 66(4):623-636.

Melville CC (2015) Distribuição espacial e determinação da depreciação quantitativa e qualitativa causada por Tetranychus ogmophallos (Acari: Tetranychidae) ao amendoinzeiro. UNESP (Dissertação de Mestrado em Agronomia).

Moraes GJ, Flechtmann CHW (2008) Manual de acarologia. Acarologia básica e ácaros de plantas cultivadas no Brasil. Holos. 288p.

Motoba K, Nishizawa $H$, Suzuki T, Hamaguchi $H$, Uchida M, Funayama S (2000) Species e specific detoxification metabolism of fenpyroximate, a potent acaricide. Pesticide Biochemistry and Physiology $67(2): 73-84$

Nadimi A, Kamali K, Arbabi M, Abdoli F (2008) Side effects of three acaricides on the predatory mite, Phytoseiulus persimilis Athias Henriot (Acari: Phytoseiidae) under laboratory conditions. Munis Entomology \& Zoology 2(3):556-567.

USDA - United States Department of Agriculture, Foreign Agricultural Service. PSD On line. Disponível em:

<http://apps.fas.usda.gov/psdonline/psdquery.aspx> Acesso em: 21 mai. 2016.

Vásquez C, Ceballos MC (2009) Suscepibilidad Susceptibilidade de Tetranychus urticae Koch (Acari: Tetranychidae) a los plaguicidas clorfenapir y abamectina en condiciones de laboratorio. Idesia 27(1):23-28.

Veronez B, Sato ME, Nicastro RL (2012) Toxicidade de compostos sintéticos e naturais sobre Tetranychus urticae e o predador Phytoseiulus macropilis. Pesquisa Agropecuária Brasileira 47(4):511-518. 